\title{
Atriocavoplasty with atrial tissue in the treatment of upper sinus-venous type interatrial communication
}

\section{Atriocavoplastia com tecido atrial no tratamento da comunicação interatrial tipo seio venoso superior}

Ulisses Alexandre CROTI, Domingo Marcolino BRAILE, Moacir Fernandes de GODOY, Aírton Camacho MOSCARDINI

RBCCV 44205-787

\section{CLINICAL DATA}

A 13-year-old white male patient from São José do Rio Preto presented with an episode of pulmonary infection at two years of age, which evolved totally asymptomatically until a recent hospitalization when the patient was in a physical and radiological state suggestive of pneumonia. On being referred to a specialist, a medial arch dilation was identified on the chest radiogram. The patient was in a good general health, acyanotic, eupneic and ruddy. His heart rhythm was regular with two clicks, split of the second noise and ejective systolic murmur $++/ 6$ at the mid left sternal border. The lungs were symmetrical and without adventitious noises as evidenced by auscultation. The abdomen was unchanged. The pulses were symmetrical and peripheral saturation was $96 \%$.

\section{ELECTROCARDIOGRAM}

The heart rhythm exhibited a sinusal pause with atrial escape at D2 and a rate of 85 beats per minute. The electrical axis of the QRS complex was indeterminate. Double positivity of the QRS was seen at V1, indicating a slight to moderate block in the right branch (Figure 1).

\section{RADIOGRAM}

The cardiac area was normal with an index of 0.45. A slight prominence of the pulmonary artery trunk with minor injury in the peribronchial space at the lung bases and signs of pulmonary vascular prominence were evidenced.

Pediatric Cardiovascular Surgery Service in São José do Rio Preto Hospital de Base - Medical School in São José do Rio Preto

Correspondence: Ulisses Alexandre Croti

Hospital de Base - FAMERP - Avenida Brigadeiro Faria Lima, 5544.

CEP 15090-000 - São José do Rio Preto - São Paulo.

Telefones: 17-97726560 / 32015025 / 32226450.

E-mail: uacroti@uol.com.br

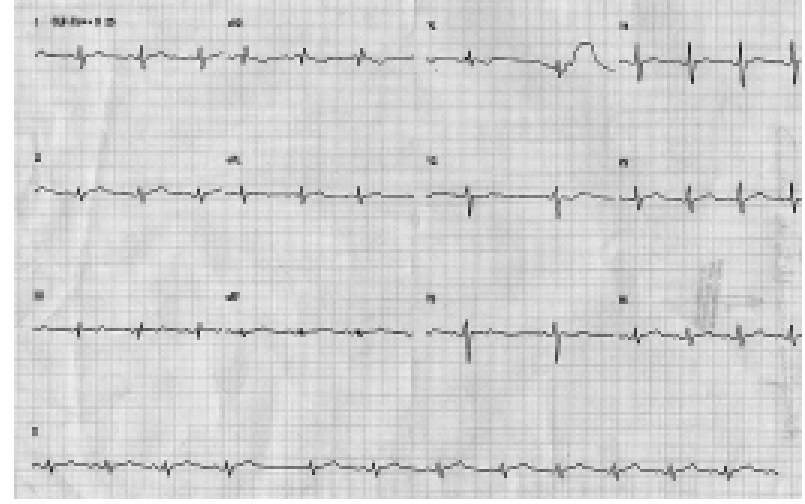

Fig. 1 - Preoperative echocardiogram

\section{ECHOCARDIOGRAM}

The echocardiogram showed situs solitus with levocardia. The veno-atrial, atrio-ventricular and ventriculo-arterial connections were concordant. Connection of the pulmonary veins to the left atrium, characterized by the flow of the upper pulmonary veins towards the superior vena cava and to the right atrium was identified. A subcaval superior sinus venosus interatrial communication of $21 \mathrm{~mm}$ at its greatest diameter was identified. Dilation of the pulmonary branches and trunk was seen. The Doppler showed slight tricuspid regurgitation, systolic pressure in the right ventricle of 39 $\mathrm{mmHg}$ and the QP/QS ratio equal to 5.0. 


\section{DIFFERENTIAL DIAGNOSIS}

Idiopathic dilation of the pulmonary trunk, aortopulmonary window, interatrial communication, partial defect of the atrioventricular canal, partial anomalous connection of the pulmonary veins and Scimitar Syndrome should all be considered.

\section{DIAGNOSIS}

With the aim of confirming the pulmonary venous connections in the left atrium and exclude other associations, a cineangiocardiographic study was indicated. This demonstrated that there was a concordant connection of the pulmonary veins in the left atrium. The right superior pulmonary vein was connected to the left atrium however its flow was towards the right atrium thus confirming the echocardiographic findings of superior sinus venosus interatrial communication.
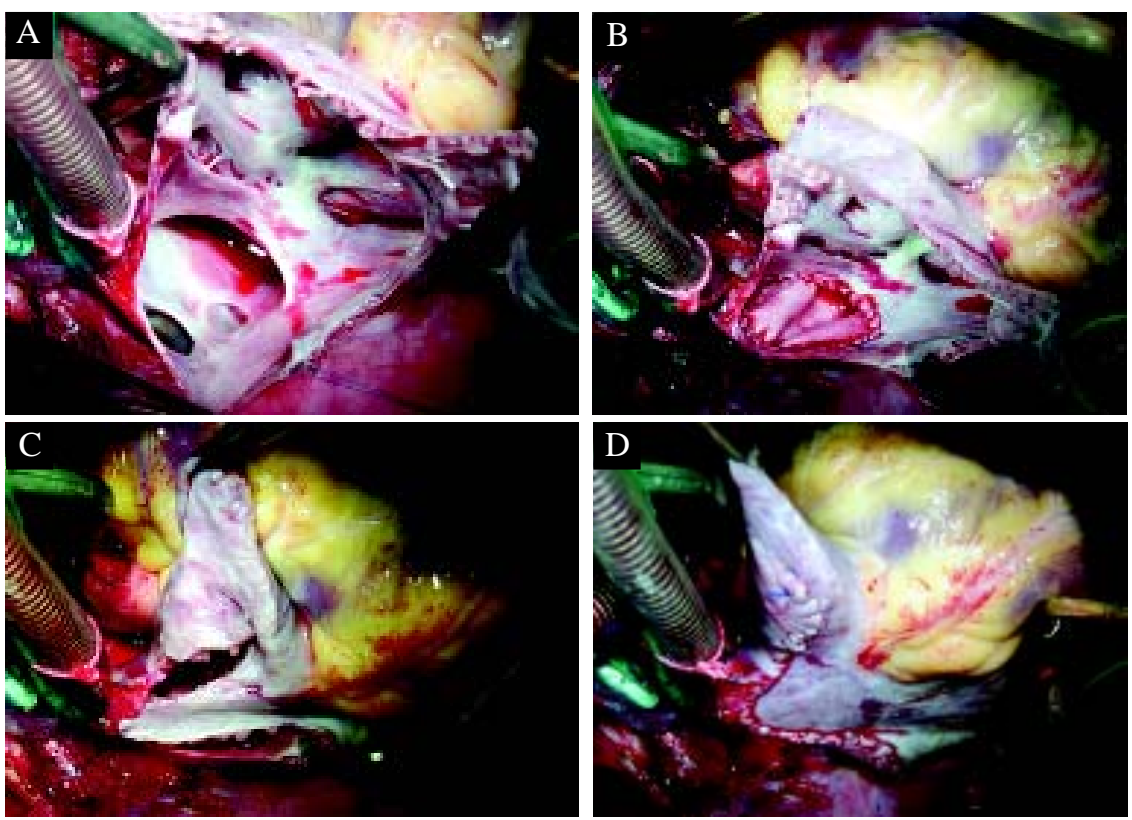

Fig. 2 - A-right atrium open where the right pulmonary veins can be seen draining into the left atrium and the flow towards the superior sinus venosus interatrial communication. $B-$ Interatrial connection closed with a bovine pericardial patch. C and D-Enlargement of the superior vena cava with tissue from the right atrium open in a " $V-Y$ " shape.

\section{OPERATION}

Medium transsternal thoracotomy was performed. A cardiopulmonary bypass was established under hypothermia of $32^{\circ} \mathrm{C}$. Intermittent anterograde sanguineous cardioplegia at $4^{\circ} \mathrm{C}$ was utilized. The right atrium was opened using the "V-Y" atrioplasty technique with the aim of enlarging the superior vena cava with tissue from the right atrial wall. The posterior incision in the right atrium was continued towards the superior vena cava sideways, avoiding injuring the sinus node or its artery. After identifying the four pulmonary veins (Figure 2), a bovine pericardium patch was sutured isolating the pulmonary veins from the left atrium (Figure 2B). The superior vena cava was enlarged with tissue from the right atrium itself (atriocavoplasty) as is demonstrated in Figures 2C and 2D [1]. The cardiopulmonary bypass time was 80 minutes and myocardial ischemia time was 62 minutes. One year after the operation, the patient presented with heart rhythm similar to the preoperative period and total correction of the defect without venous obstructions verified by echocardiography. It is important to stress that this technique is extremely useful and easily reproduced both for patients with superior sinus venosus interatrial communications and for those with partial anomalous connections of the pulmonary veins [2].

\section{BIBLIOGRAPHIC REFERENCES}

1. DeLeon SY, Freeman JE, Ilbawi MN, Husayni TS, Quinones JA, Ow EP et al. Surgical techniques in partial anomalous pulmonary veins to the superior vena cava. Ann Thorac Surg. 1993;55(5):1222-6.

2. Dervanian P, Mace L, Puyo P, Folliguet TA, Abdelmoulah S, Santoro $\mathrm{F}$ et al. Techniques of correction of partial right abnormal pulmonary venous return associated with atrial septal defect. Arch Mal Coeur Vaiss. 1996;89(7):857-63. 